\title{
Predictive factors of burnout syndrome in nursing students at a public university*
}

\author{
Fatores preditivos da síndrome de burnout em acadêmicos \\ de enfermagem de uma universidade pública \\ Factores predictivos del síndrome de burnout en académicos \\ de enfermería de una universidad pública
}

How to cite this article:

Vasconcelos EM, Trindade CO, Barbosa LR, De Martino MMF. Predictive factors of burnout syndrome in nursing students at a public university. Rev Esc Enferm USP. 2020;54:e03564. doi: https://doi.org/10.1590/S1980-220X2018044003564

\section{Eduardo Motta de Vasconcelos ${ }^{1,2}$ \\ Charlene Oliveira Trindade ${ }^{2}$ \\ Luciene Rodrigues Barbosa ${ }^{1}$ \\ Milva Maria Figueiredo De Martino $^{1}$}

* Extracted from the thesis: "Avaliação de efetividade do biofeedback como estratégia de manejo da síndrome de burnout: um ensaio clínico randomizado", Programa de Pós-Graduação em Enfermagem, Universidade Federal de São Paulo, 2018.

${ }^{1}$ Universidade Federal de São Paulo, Escola Paulista de Enfermagem, Programa de PósGraduação em Enfermagem, São Paulo, SP, Brazil.

${ }^{2}$ Hospital Municipal Prof. Dr. Alípio

Corrêa Netto, Departamento de

Enfermagem, São Paulo, SP, Brazil.

\begin{abstract}
Objective: To identify the prevalence and analyze the existence of predictive factors of burnout syndrome in nursing students of a public university unit. Method: A quantitative, descriptive, and cross-sectional study. Data were collected from two instruments: a sociodemographic instrument and the Maslach Burnout Inventory - Student Survey. Simple and multiple logistic regression models were adjusted to assess the association between variables. Results: There were 100 students who participated in the research, of which $20 \%$ presented burnout syndrome. Second $(p=0.036)$ and third year students $(p=0.046)$, those using medication $(p=0.002)$ and those considering dropping out ( $p$ $=0.001$ ) were significantly associated with burnout. Only students who were thinking of dropping out of the course $(p=0.025)$ maintained a significant association in the multiple logistic regression model, which means that the probability of an individual from the population from which the sample was extracted presenting burnout syndrome was higher in this variable. Conclusion: The burnout syndrome prevalence corresponded to $20 \%$. The predictors of burnout were: second and third years of the course, use of medication and thinking of dropping out from the course.
\end{abstract}

\section{DESCRIPTORS}

Students, Nursing; Education, Nursing; Stress, Psychological; Mental Health.

Corresponding author:

Eduardo Motta de Vasconcelos

Rua Fontoura Xavier, 951, Ap. 04, Itaquera

CEP: 08295-300 - São Paulo, SP, Brazil. 


\section{INTRODUCTION}

In the 1930s of the $20^{\text {th }}$ century, Hans Selye coined the concept of the term "stress" as the state which manifests itself through the general syndrome of adaptation, which consists of a set of reactions that occurs in the body when subjected to situations exceeding their natural regulatory capacity ${ }^{(1)}$. When the individual is influenced by psychosocial factors in the workplace, and these are unfavorable to their professional development, it may result in increased occupational stress, which in turn over the years can trigger burnout syndrome $\mathrm{e}^{(2-3)}$.

The term burnout was first conceptualized by Herbert J. Freudenberger; however, the most accepted definition by the scientific community today is the one by Maslach and Jackson based on the social-psychological perspective, characterized by a process consisting of three dimensions (emotional exhaustion, disbelief and low professional achievement), in which an individual reaches a collapse in their adaptive capacity ${ }^{(4)}$. This occurs when stress related to the work environment goes beyond adaptive levels without effective coping, thus becoming chronic ${ }^{(2)}$. This is a multidimensional syndrome in which occupational stress chronicity occurs when coping strategies are insufficient ${ }^{(2-3)}$.

There is a predominance of this syndrome in professions dealing with people, arising as a result of interpersonal and organizational relationships ${ }^{(2)}$. In addition, it has specific symptoms such as irritability, increased aggression, difficulty concentrating, skepticism, tendency to isolation, as well as constant and progressive fatigue ${ }^{(5)}$.

In mid-1974, Freudenberger noted that many of the volunteers he worked with showed progressive loss of their emotions, motivation, and performance. Thus, the concept of burnout syndrome was modified and expanded through his articles. It was not until 2002 that research with academics began to gain atraction, especially after a study which confirmed the three-factor structure of the Maslach Burnout Inventory (MBI) - General Survey (GS), an instrument which studies the syndrome in workers, in undergraduate students from various areas ${ }^{(6)}$.

The syndrome in students consists of three peculiar factors or dimensions $s^{(5)}$. The emotional exhaustion dimension refers to the feeling of being exhausted due to the intense demands and the high demand for studying. The disbelief dimension is assimilated as the manifestation of a cynical attitude, seeking to distance themselves from their studies. And the professional effectiveness dimension is characterized by the perception of being incompetent ${ }^{(7)}$.

Burnout syndrome can begin in the academic phase, meaning in the training and preparation period for professional practice, especially in nursing students since they perform similar activities to those of professionals in the area and are influenced by the clinical practice environment ${ }^{(8)}$. The considered predictive factors are only facilitators or not, as they have different specific weights in each individual ${ }^{(8-9)}$.

The syndrome occurs in nursing students due to a sum of factors such as: sociodemographic characteristics, lack of knowledge of the clinical practice environment, fear of causing harm to the patient, confrontation with death, lack of acceptance and recognition in the internship by the different health teams ${ }^{(5,8,10)}$.

Burnout syndrome is still unknown among most professionals and undergraduate students ${ }^{(5,8,11)}$. However, there is a lack of preventive programs in national institutions which seek detection as well as reducing its incidence and prevalence in academics ${ }^{(3)}$.

The need for this study is justified by the importance of knowing the relationship between the academic activities of the nursing course and burnout syndrome, since the results found may support implementing a prevention program and studies with intervention protocols for confronting it at the institution where the research was conducted. It is believed that in future investigations these measures may impact on reducing the prevalence of burnout syndrome, a reduction in the dropout rate and improvement in the academic performance in the internships and disciplines of the institution.

The guiding questions of the research were: What is the prevalence of burnout syndrome in nursing students of a public university unit? Are there factors which can be considered predictive of the syndrome in nursing students? Thus, this study aimed to identify the prevalence and analyze the existence of predictive factors of burnout syndrome in nursing students of a public university unit in order to know the profile of the most vulnerable students for which interventions in future research should be prioritized.

\section{METHOD}

\section{STUDY DESIGN}

This is a quantitative, descriptive, and cross-sectional study.

\section{SCENARIO}

The study was conducted at a public university unit in the city of São Paulo (SP), Brazil. The unit offers a bachelor's degree course in nursing taught full time and lasting 4 years.

\section{SelECTION CRITERIA}

The following inclusion criteria were adopted: to be a student in the first to fourth year of nursing, healthy, of both genders, and aged 18 years or older. Exclusion criteria were: not accepting to participate in the study, previous diagnosis of systemic arterial hypertension, hypothyroidism, previous psychiatric diagnosis by an experienced psychiatrist, compulsory internship removal, maternity leave or illness. Respecting these criteria, two students with a diagnosis of systemic arterial hypertension, two with a diagnosis of hypothyroidism and 213 individuals who refused to participate in the study were excluded.

Non-probabilistic convenience sampling was used to define the sample. Nursing students from the first to the fourth year were selected according to their willingness to participate in the study and after agreeing to sign the Informed Consent Form (ICF). The course had a total of 317 students enrolled, but the sample consisted of 100 . 
This study did not present a sample calculation, as all possible students (who agreed to participate) participated. In addition, the responsible researcher chose to perform a previous analysis with 80 students, which showed a significant association between some variables, showing that the total number of selected participants $(n=100)$ was adequate, being large enough that the probability of finding a significant association between the variables would be high.

\section{Data collection}

Students were invited to participate in the study in person and by email. The researcher in charge performed data collection between March and May 2017 by scheduling according to the participants' availability. The students responded to the self-applied instruments after signing the informed consent. Sociodemographic data collection form and the Maslach Burnout Inventory (MBI) in its Student Survey (SS) version were used. The instruments were filled in in a reserved place of the university unit and then delivered to the lead researcher to maintain the confidentiality and privacy of the students.

\section{DATA ANALYSIS AND PROCESSING}

The sociodemographic data collection form was used to draw the profile of the participants, consisting of multiple choice and open questions, covering: year of the course, study shift, age, gender, marital status, children, funding for covering the costs to study, own income, employment, physical activity, college absenteeism, use of medication due to studies, thinking of dropping out of school and living with others.

The student-oriented MBI-SS was used in its translated version, adapted and validated by Carlotto and Câmara, in order to identify the percentage of students with burnout syndrome $^{(12)}$. This instrument has 15 questions which are subdivided into three subscales or dimensions. Questions 1, 4, 6, 8 and 12 are related to emotional exhaustion (5 items); questions 2, 9, 10 and 14 are related to disbelief (4 items); while questions $3,5,7,11,13$ and 15 are related to professional effectiveness (6 items). All items are evaluated on a seven-point Likert scale ranging from 0 (never) to 6 (always) ${ }^{(12)}$. According to a study to validate the same version of the instrument performed with Spanish students, the Cronbach's alpha coefficient for emotional exhaustion was 0.74 , for disbelief it was 0.79 , and for professional effectiveness it corresponded to 0.76 , showing that this is a reliable instrument ${ }^{(13)}$.

For classifying the level in each subscale, students with a score up to $50 \%$ will be considered as low level, and above this value as a high level in the subscale in question ${ }^{(14)}$. Thus, the syndrome is present when a student has a high level of emotional exhaustion, a high level of disbelief, and a low level of professional effectiveness ${ }^{(12)}$.

The results in the descriptive analysis of categorical variables are expressed by frequency and percentage tables, while the results for the numerical variables are expressed by position and dispersion measures, such as: mean, median, standard deviation, minimum and maximum values. Simple (univariate) logistic regression models were adjusted to assess the association between two categorical variables. In addition, a multiple logistic regression model (multivariate) was adjusted for each of these variables to assess the percentage of participants with the presence of the syndrome, with possible predictive factors among those with $\mathrm{p}<0.20(20.0 \%)$ in the univariate logistic regression results.

The odds ratio (OR) values and the significance of each category in relation to the base category on the model adjusted were obtained (percentages of correctly classified cases, the Omnibus coefficient test to verify acceptance of the global model and the Hosmer-Lemeshow test to verify adjustment to the model) in each univariate or multivariate logistic regression model. The Backward selection process was used to include the variables in the model due to the higher number of significant variables in assessing the presence of the syndrome. The significance level of $5 \%(\mathrm{p}<0.05)$ in statistical test decisions and $95 \%$ confidence intervals were used. Data were entered in the Microsoft Office Excel 2007 spreadsheet and IMB ${ }^{\circledR}$ SPSS $^{\circledast}$ Statistics version 23 software were used to obtain statistical calculations.

\section{ETHICAL ASPECTS}

After authorization from the educational institution, the study was submitted to the Ethics in Research Committee and was approved by the Opinion No. 1.887.032/2017. The research development met the ethical principles of Resolution 466/2012 of the National Council of Health, which regulates research involving human beings in Brazil.

\section{RESULTS}

Respecting the established inclusion and exclusion criteria, the total number of study participants was 100 nursing students. Their ages ranged from 18 to 57 years, with a median of 21 years and a mean of 22.93 (standard deviation $=5.22$ ). From the participants, $91 \%$ were female and single. The distribution of age groups was uneven, with $87 \%$ being between 18 and 27 years old, and 94\% said they did not have any children. There were $36 \%$ in their first year of the course. Most reported not having a job (84\%), not taking medication (77\%), not thinking of dropping out of school (65\%) and living with friends or family (95\%).

According to the MBI-SS results, the percentages of individuals with high level of emotional exhaustion, high level of disbelief and low level of professional effectiveness were, respectively: $75 \%, 29 \%$ and 33\%, while the prevalence of burnout syndrome in the students was high, corresponding to $20 \%$ $(n=20)$. Table 1 shows the profile of nursing students with burnout, and it is important to highlight that all were single, had no job, children or their own income. In addition, 70\% said they thought about dropping out of the course.

Table 2 presents the descriptive results and univariate logistic regressions, seeking to assess the association between possible predictive factors and the occurrence of burnout syndrome. Participants who were in the second year of the course $(p=0.036)$, in the third year of the course $(p=0.046)$, those who used medication $(p=0.002)$ and those thinking of dropping out $(\mathrm{p}=0.001)$ were significantly associated with the occurrence of burnout syndrome. 
Table 1 - Profile of nursing students with burnout according to sociodemographic, economic and lifestyle-related variables São Paulo, SP, Brazil, 2017.

\begin{tabular}{|c|c|c|c|}
\hline \multirow{2}{*}{ Variable } & \multicolumn{3}{|c|}{ Nursing Students with Burnout } \\
\hline & Categories & $\mathbf{n}$ & $\%$ \\
\hline Gender & Female & 19 & 95 \\
\hline Age range (years) & 18 to 27 & 19 & 95 \\
\hline Civil status & Single & 20 & 100 \\
\hline Year in the course & Third & 8 & 40 \\
\hline Employment & No & 20 & 100 \\
\hline Children & No & 20 & 100 \\
\hline Financing their costs & Family & 20 & 100 \\
\hline Own income & No & 20 & 100 \\
\hline Practicing physical activity & No & 12 & 60 \\
\hline $\begin{array}{l}\text { Frequency of absenteeism in } \\
\text { the course }\end{array}$ & $\begin{array}{l}\text { One or more times } \\
\text { in a month }\end{array}$ & 13 & 65 \\
\hline Use medication & $\begin{array}{l}\text { Never/One or more } \\
\text { times in a month }\end{array}$ & $10 / 10$ & $50 / 50$ \\
\hline $\begin{array}{l}\text { Thinking of dropping out of } \\
\text { the course }\end{array}$ & $\begin{array}{l}\text { One or more times } \\
\text { in a month }\end{array}$ & 14 & 70 \\
\hline Living situation & Family & 18 & 90 \\
\hline
\end{tabular}

As shown in Table 3, among the three variables included in the multivariate logistic regression model, only students thinking about dropping out $(\mathrm{p}=0.025)$ maintained a significant association with the occurrence of burnout syndrome. Through the OR of this variable, it was possible to verify that the probability of a student of the population from which the sample was extracted presenting burnout syndrome is higher in those who thought of dropping out of the course.

The evaluation of the adjusted model found in Table 3 showed agreement between the observed and predicted values, correctly classifying the cases in $85.0 \%$ of the students. The overall model was accepted $(p=0001)$ according to the Omnibus coefficient test and it was well adjusted ( $\mathrm{p}$ $=0.629)$ according to the Hosmer-Lemeshow test.

Table 2 - Univariate logistic regression results for burnout syndrome according to sociodemographic, economic and lifestyle-related variables - São Paulo, SP, Brazil, 2017.

\begin{tabular}{|c|c|c|c|c|c|c|}
\hline \multirow{3}{*}{ Variable } & \multicolumn{6}{|c|}{ Burnout Syndrome } \\
\hline & \multicolumn{2}{|c|}{ Present } & \multicolumn{2}{|c|}{ Absent } & \multirow{2}{*}{ p-value } & \multirow{2}{*}{ OR $(95 \% \mathrm{Cl})$} \\
\hline & $\mathbf{n}$ & $\%$ & $\mathbf{n}$ & $\%$ & & \\
\hline \multicolumn{7}{|l|}{ Gender } \\
\hline Male & 1 & 11.1 & 8 & 88.9 & - & 1.00 \\
\hline Female & 19 & 20.9 & 72 & 79.1 & 0.494 & 2.11 (0.25 to 17.93$)$ \\
\hline \multicolumn{7}{|l|}{ Age range (years) } \\
\hline 18 to 27 & 19 & 21.8 & 68 & 78.2 & 0.259 & 3.35 (0.41 to 27.45$)$ \\
\hline 28 to 57 & 1 & 7.7 & 12 & 92.3 & - & 1.00 \\
\hline \multicolumn{7}{|l|}{ Civil status } \\
\hline Single & 20 & 22.0 & 71 & 78.0 & - & - \\
\hline Married & - & - & 9 & 100.0 & & \\
\hline Year in the course & & & & & $0.036^{*}$ & \\
\hline First & 4 & 11.1 & 32 & 88.9 & 0.726 & 1.37 (0.23 to 8.17$)$ \\
\hline Second & 6 & 37.5 & 10 & 62.5 & $0.036^{*}$ & $6.60(1.13$ to 38.60$)$ \\
\hline Third & 8 & 33.3 & 16 & 66.7 & $0.046^{*}$ & $5.50(1.03$ to 29.45$)$ \\
\hline Fourth & 2 & 8.3 & 22 & 91.7 & - & 1.00 \\
\hline \multicolumn{7}{|l|}{ Employment } \\
\hline No & 20 & 23.8 & 64 & 76.2 & - & - \\
\hline Yes & - & - & 16 & 100.0 & & \\
\hline \multicolumn{7}{|l|}{ Children } \\
\hline No & 20 & 21.3 & 74 & 78.7 & - & - \\
\hline Yes & - & - & 6 & 100.0 & & \\
\hline \multicolumn{7}{|l|}{ Financing of costs } \\
\hline Family & 20 & 27.0 & 54 & 73.0 & - & - \\
\hline Own & - & - & 26 & 100.0 & & \\
\hline \multicolumn{7}{|l|}{ Own income } \\
\hline No & 20 & 27.4 & 53 & 72.6 & - & - \\
\hline Yes & - & - & 27 & 100.0 & & \\
\hline \multicolumn{7}{|l|}{ Practicing physical activity } \\
\hline No & 12 & 21.1 & 45 & 78.9 & 0.762 & 1.17 (0.43 to 3.16$)$ \\
\hline Yes & 8 & 18.6 & 35 & 81.4 & - & 1.00 \\
\hline \multicolumn{7}{|c|}{ Frequency of absenteeism in the course } \\
\hline Never & 7 & 16.3 & 36 & 83.7 & - & 1.00 \\
\hline One or more times in a month & 13 & 22.8 & 44 & 77.2 & 0.421 & $1.52(0.55$ to 4.21$)$ \\
\hline \multicolumn{7}{|l|}{ Use medication } \\
\hline Never & 10 & 13.0 & 67 & 87.0 & - & 1.00 \\
\hline One or more times in a month & 10 & 43.5 & 13 & 56.5 & $0.002 *$ & 5.15 (1.79 to 14.86$)$ \\
\hline \multicolumn{7}{|c|}{ Thinking of dropping out of the course } \\
\hline Never & 6 & 9.2 & 59 & 90.8 & - & 1.00 \\
\hline One or more times in a month & 14 & 40.0 & 21 & 60.0 & $0.001 *$ & $6.56(2.23$ to 19.27$)$ \\
\hline \multicolumn{7}{|l|}{ Living situation } \\
\hline Alone & 2 & 40.0 & 3 & 60.0 & 0.270 & $2.85(0.44$ to 18.34$)$ \\
\hline With friends or family & 18 & 18.9 & 77 & 81.8 & - & 1.00 \\
\hline
\end{tabular}


Table 3 - Univariate and multivariate logistic regression results for the occurrence of burnout syndrome according to sociodemographic and lifestyle-related variables through the Backward selection process - São Paulo, SP, Brazil, 2017.

\begin{tabular}{|c|c|c|c|c|}
\hline \multirow{2}{*}{ Variable } & \multicolumn{2}{|c|}{ Univariate } & \multicolumn{2}{|c|}{ Multivariate } \\
\hline & p-value & OR $(95 \% \mathrm{CI})$ & p-value & OR $(95 \% \mathrm{CI})$ \\
\hline Year in the course & $0.036^{*}$ & & 0.193 & \\
\hline First & 0.726 & $1.37(0.23$ to 8.17$)$ & 0.928 & $0.92(0.14$ to 6.13$)$ \\
\hline Second & $0.036^{*}$ & $6.60(1.13$ to 38.60$)$ & 0.113 & $4.65(0.70$ to 31.08$)$ \\
\hline Third & $0.046^{*}$ & $5.50(1.03$ to 29.45$)$ & 0.446 & $2.07(0.32$ to 13.56$)$ \\
\hline Fourth & - & 1.00 & - & 1.00 \\
\hline \multicolumn{5}{|l|}{ Use of medication } \\
\hline Never & - & 1.00 & - & 1.00 \\
\hline One or more times in a month & $0.002 *$ & 5.15 (1.79 to 14.86$)$ & 0.057 & $3.19(0.97$ to 10.51$)$ \\
\hline \multicolumn{5}{|c|}{ Thinking of dropping out of the course } \\
\hline Never & - & 1.00 & - & 1.00 \\
\hline One or more times in a month & $0.001 *$ & $6.56(2.23$ to 19.27$)$ & $0.025^{*}$ & $4.12(1.19$ to 14.28$)$ \\
\hline
\end{tabular}

Note: OR: Odds Ratio. Cl: Confidence Interval. (*): Significant p-value. $(\mathrm{n}=100)$

\section{DISCUSSION}

According to national studies conducted with nursing students, it was found that they were predominantly female, single, young, without children, did not work and lived with their families ${ }^{(7,10)}$. These studies confirm the same profile found in the present study and show a new reality in the country in which women, who are the majority in health professions which involve caring, are preferring to start a family after achieving financial stability and establishing themselves in the labor market ${ }^{(15-16)}$.

The prevalence of burnout syndrome in a survey of 570 nursing students in Brazil corresponded to $24.74 \%{ }^{(10)}$. Burnout rates in similar samples made up of medical students ranged from $13.1 \%$ to $71 \%{ }^{(17-19)}$. Thus, it can be said that the index of this study was similar to that found in nursing students and some studies with medical students ${ }^{(10,18)}$. However, the prevalence found exceeded the rate of another study conducted with nurses and nursing technicians (professionals) $^{(20-21)}$. Therefore, there is a high prevalence, showing the need for implementing institutional prevention programs, as well as studies with intervention protocols for their coping, since these students can be removed from their activities even before joining the labor market as professionals, as well as the social and family context.

Regarding the profile of nursing students with burnout syndrome when comparing the results with a study with a similar sample made up of dental students, it was found that most were single, young (between 18 and 28 years), had no children, were in their third year, were using medication and thought of dropping out of the course, corroborating the result found herein ${ }^{(22)}$.

The results found in the literature regarding the relationship between burnout syndrome and gender and age variables differ ${ }^{(7,23-25)}$. An international study conducted with nursing students from a university in Spain showed that the gender variable showed no significant difference in any dimension of the syndrome ${ }^{(24)}$. However, the authors believe that the study design does not enable elucidating the issue, requiring further longitudinal studies with paired groups of both genders to evaluate this relationship.

Regarding age, a study conducted with nursing students from northern Spain showed that there was a relationship between age and lower levels of burnout syndrome, i.e. older participants had lower levels of burnout syndrome ${ }^{(25)}$. Although the present study presents a higher prevalence of burnout among younger students (21.8\%), there was no significant association with age. However, the literature points out that nursing students are considered inexperienced and end up becoming more tense when suffering situations experienced in the clinical practice environment, as well as having negative feelings about theoretical and practical activities $^{(5,10)}$, being influenced by occupational stress, which over the years may be a facilitator of the occurrence of burnout syndrome ${ }^{(20)}$.

Although the literature shows divergent results on the relationship between civil/marital status and the occurrence of burnout syndrome, it is important to emphasize a study conducted in Cameroon with nursing students which showed a significant association between these variables, which is in contrast to the present study ${ }^{(7,26)}$. Some authors believe that having a stable affective relationship can be considered a protective factor for the syndrome ${ }^{(21)}$.

National studies showed that nursing students in their second year and third year of undergraduate study did not show a significant relationship with the occurrence of burnout syndrome ${ }^{(7,16)}$; a result confirmed by research with dentistry students ${ }^{(22,23)}$. It is possible that there was a significant association between the second year and the third year of the course with the occurrence of burnout syndrome in the present study due to the high demands of the studies, the increased workload devoted to university extension activities to achieve the credits needed to advance to the fourth year, to the higher workload in the clinical practice environment and to the students' difficulties related to the pediatrics and women's health disciplines.

As shown by studies with nursing students, there was a significant relationship between the occurrence of burnout 
syndrome and the variables work ${ }^{(7)}$ and children ${ }^{(26)}$, contrary to the present study. Those students who worked while studying undergraduate nursing were associated with the three dimensions of the syndrome, only negatively influencing the professional effectiveness factor ${ }^{(7)}$. Students with children are believed to have a lower rate of burnout syndrome, as this is possibly a protective factor given that these individuals have greater responsibility, resilience and more realistic expectations due to maternity or paternity ${ }^{(21)}$.

Studies found in the national literature show that most nursing and dental students with burnout syndrome had family-financed costs and lived with friends or family, but there was no significant relationship with the occurrence of burnout syndrome, confirming the results of this research ${ }^{(7,23)}$.

Regarding the relationship between burnout syndrome and physical activity, a study with medical students showed that there was a significant association between low physical activity and the occurrence of burnout syndrome, which is opposite to the present study ${ }^{(27)}$.

According to studies found in the national literature regarding the use of medication, the prevalence of burnout syndrome was higher in students who used medication, and there was a significant relationship ${ }^{(22,23)}$. Other international research conducted with nursing and medical scholars has shown that burnout syndrome is considered an independent predictor of recreational drug use ${ }^{(28)}$. Thus, it is evident that individuals with the syndrome use medications seeking to inhibit symptoms, often by self-medication, without seeking medical or psychological care. It is common to find professionals who have difficulty making an accurate diagnosis or even to define an appropriate treatment, as it is often diagnosed as depression or stress, in turn causing clinical worsening and underreporting ${ }^{(3,29-30)}$.

There was a significant association between the students who thought of dropping out of the course and burnout syndrome occurrence, showing that the result was consistent ${ }^{(7,23,26)}$. An international survey showed that nursing students showed regret that they chose the course as a future profession, and this variable is considered an independent determinant of burnout ${ }^{(26)}$.

The study had the small sample size as a limitation, since the results could be even more significant by increasing the number of students. Another limiting factor is the lack of evaluation by an experienced psychologist or psychiatrist to confirm the diagnosis of burnout syndrome. However, this was a preliminary study which served as the basis for elaborating an intervention clinical trial in the institution, because it was possible to define the predictive factors of burnout syndrome from this analysis and to match the number of students with burnout syndrome in the control and intervention groups.

\section{CONCLUSION}

The prevalence of nursing students with burnout syndrome corresponded to $20 \%$ of the sample. The students who were in the second $(p=0.036)$ and the third years of the course $(p=0.046)$, those who used medication $(p=0.002)$ and those who thought of dropping out of the course $(\mathrm{p}=$ 0.001) were significantly associated with burnout syndrome occurrence, which are considered predictive factors. This study contributes to scientific knowledge in mental health, since the prevalence was high and predictive factors of the syndrome were identified, and these results are relevant to the literature.

Among the variables which were included in the multivariate logistic regression model, it was found that only students who thought of dropping out of the course $(p=0.025)$ maintained a significant association with the occurrence of burnout syndrome. The data enable a reflection on the training process and mental health support of nursing students, since most who thought of dropping out of the course presented the syndrome, showing that it could be removed from the academic scope. Thus, it is pertinent to insert alternative therapies (such as biofeedback and mindfulness) through prevention programs and intervention protocol studies to assist them in stress management during undergraduation, contributing to their professional education, considering that this can provide greater emotional balance resulting in better performance in the courses, and better preparing them for the transition to being professionals inserted in the work environment.

Future studies should analyze the impact of prevention programs and intervention protocols and the different relationships between other variables and the occurrence of burnout in public and private institutions, such as variables related to the student's past history, personality traits, resilience, teaching methodologies and university subjects.

RESUMO

Objetivo: Identificar a prevalência e analisar a existência de fatores preditivos do burnout em acadêmicos de enfermagem de uma unidade universitária pública. Método: Estudo quantitativo, descritivo, transversal. Utilizou-se, na coleta de dados, de dois instrumentos: um sociodemográfico e o Maslach Burnout Inventory - Student Survey. Para avaliar a associação entre as variáveis foram ajustados modelos de regressões logísticas simples e múltipla. Resultados: Participaram da pesquisa 100 estudantes. Apresentaram a síndrome $20 \%$ da amostra. Os acadêmicos do segundo ( $\mathrm{p}=$ $0,036)$ e do terceiro anos da graduação $(p=0,046)$, os que utilizavam medicamento $(p=0,002)$ e os que pensavam em desistir do curso $(p=0,001)$ apresentaram associação significativa com o burnout. No modelo de regressão logística múltipla, apenas os acadêmicos que pensavam em desistir do curso $(p=0,025)$ mantiveram associação significativa, ou seja, a probabilidade de um indivíduo da população da qual a amostra foi extraída apresentar a síndrome foi mais elevada nesta variável. Conclusão: A prevalência da síndrome correspondeu a 20\%. Os fatores preditivos do burnout foram: segundo e terceiro anos da graduação, uso de medicamento e pensamento de desistir do curso.

\section{DESCRITORES}

Estudantes de Enfermagem; Educação em Enfermagem; Estresse Psicológico; Saúde Mental.

\section{RESUMEN}

Objetivo: Identificar la prevalencia y analizar la existencia de factores predictivos del burnout en académicos de enfermería de una unidad universidad pública. Método: Estudio cuantitativo, descriptivo, transversal. Se emplearon, en la recolección de datos, dos instrumentos: 
uno sociodemográfico y el Maslach Burnout Inventory - Student Survey. Para evaluar la asociación entre las variables fueron ajustados modelos de regresión logística simple y múltiple. Resultados: Participaron en la investigación 100 estudiantes. Presentaron el síndrome el $20 \%$ de la muestra. Los académicos del segundo $(\mathrm{p}=0,036)$ y del tercer curso del pregrado $(\mathrm{p}=0,046)$, quienes utilizaban medicamento $(p=0,002)$ y quienes pensaban en desistir de la carrera $(p=0,001)$ presentaron asociación significativa con el burnout. En el modelo de regresión logística múltiple, solo los académicos que pensaban en desistir de la carrera $(\mathrm{p}=0,025)$ mantuvieron asociación significativa, es decir, la probabilidad de que un individuo de la población de la que se extrajo la muestra presente el síndrome fue más elevada en esta variable. Conclusión: La prevalencia del síndrome correspondió al 20\%. Los factores predictivos del burnout fueron: segundo y tercer cursos del pregrado, empleo de medicamento y pensamiento de desistir de la carrera.

\section{DESCRIPTORES}

Estudiantes de Enfermería; Educación en Enfermería; Estrés Psicológico; Salud Mental.

\section{REFERENCES}

1. Selye H. The syndrome produced by diversenoxious agents. Nature. 1936;138:32-4. Republished from: J Neuropsychiatry Clin Neurosci. 1998;10(2):230-1. DOI: https://doi.org/10.1176/jnp.10.2.230a

2. Khamisa N, Oldenburg B, Peltzer K, Ilic D. Work related stress, burnout, job satisfaction and general health of nurses. Int J Environ Res Public Health [Internet]. 2015 [cited 2018 Oct 11];12(1):652-66. Available from: https://www.ncbi.nlm.nih.gov/pmc/articles/PMC4306884/

3. Vasconcelos EM, Martino MMF, França SPS. Burnout and depressive symptoms in intensive care nurses: relationship analysis. Rev Bras Enferm [Internet]. 2018 [cited 2018 Oct 11];71(1):135-41. Available from: http://www.scielo.br/pdf/reben/v71n1/0034-7167reben-71-01-0135.pdf

4. Maslach C, Jackson SE. The measurement of experienced Burnout. Journal of Occupational Behavior [Internet]. 1981 [cited 2019 Mar 09];2:99-113. Available from: https://smlr.rutgers.edu/sites/default/files/documents/faculty_staff_docs/TheMeasurementofExperiencedBur nout.pdf

5. Tomaschewski-Barlem JG, Lunardi VL, Ramos AM, Silveira RS, Barlem ELD, Ernandes CM. Signs and symptoms of the burnout syndrome among undergraduate nursing students. Texto Contexto Enferm [Internet]. 2013 [cited 2018 Oct 11];22(3):754-62. Available from: http:// www.scielo.br/pdf/tce/v22n3/en_v22n3a23.pdf

6. Schaufeli WB, Salanova M, González-Romá V, Bakker AB. The measurement of burnout and engagement: a confirmatory factor analytic approach. J Happiness Stud [Internet]. 2002 [cited 2018 Oct 11];3:71-92. Available from: https://www.wilmarschaufeli.nl/publications/ Schaufeli/178.pdf

7. Tomaschewski-Barlem JG, Lunardi VL, Lunardi GL, Barlem ELD, Silveira RS, Vidal DAS. Burnout syndrome among undergraduate nursing students at a public university. Rev Latino Am Enfermagem [Internet]. 2014 [cited 2018 Oct 11];22(6):934-41. Available from: http://www. scielo.br/pdf/rlae/v22n6/0104-1169-rlae-3254-2498.pdf

8. Rees CS, Heritage B, Osseiran-Moisson R, Chamberlain D, Cusack L, Anderson J, et. al. Can We Predict Burnout among Student Nurses? An Exploration of the ICWR-1 Model of Individual Psychological Resilience. Front Psychol [Internet]. 2016 [cited 2018 Oct 11];7:1072. Available from: https://www.ncbi.nlm.nih.gov/pmc/articles/PMC4949488/pdf/fpsyg-07-01072.pdf

9. Hegney DG, Craigie M, Hemsworth D, Osseiran-Moisson R, Aoun S, Francis K, et. al. Compassion satisfaction, compassion fatigue, anxiety, depression and stress in registered nurses in Australia: study 1 results. J Nurs Manag. 2014;22(4):506-18. DOI: https://doi.org/10.1111/ jonm.12160

10. Silva RM, Goulart CT, Lopes LFD, Serrano PM, Costa ALS, Guido LA. Hardy personality and burnout syndrome among nursing students in three Brazilian universities-an analytic study. BMC Nurs [Internet]. 2014 [cited 2018 Oct 11];13(1):9. Available from: https://www.ncbi. nlm.nih.gov/pmc/articles/PMC3975133/

11. Lopes FL, Guimaraes GS. Estudo da síndrome de burnout em estudantes de psicologia. Psicol Ensino Form [Internet]. 2016 [citado 2018 out. 11];7(1):40-58. Disponível em: http://pepsic.bvsalud.org/pdf/pef/v7n1/v7n1a05.pdf

12. Carlotto MS, Nakamura AP, Câmara SG. Síndrome de Burnout em estudantes universitários da área da saúde. Psico (Porto Alegre) [Internet]. 2006 [citado 2018 out. 11];37(1):57-62. Disponível em: http://revistaseletronicas.pucrs.br/ojs/index.php/revistapsico/article/ view/1412/1111

13. Schaufeli WB, Martinez IM, Pinto AM, Salanova M, Bakker AB. Burnout and engagement in university students: a Cross National Study. J Cross Cult Psychol [Internet]. 2002 [cited 2019 Mar 09];33(5):464-81. Available from: https://www.isonderhouden.nl/doc/pdf/arnoldbakker/ articles/articles_arnold_bakker_78.pdf

14. Tomaschewski-Barlem JG, Lunardi VL, Lunardi GL, Barlem ELD, Silveira RS, Vidal DA. Burnout syndrome among undergraduate nursing students at a public university. Rev Latino Am Enfermagem [Internet]. 2014 [cited 2018 Oct 11];22(6):934-41. Available from: https://www. ncbi.nlm.nih.gov/pmc/articles/PMC4309227/

15. França FM, Ferrari R. Burnout syndrome and the socio-demographic aspects of nursing professionals. Acta Paul Enferm [Internet]. 2012 [cited 2019 Aug 06];25(5):743-8. Available from: http://www.scielo.br/pdf/ape/v25n5/en_15.pdf

16. Al-Alawi M, Al-Sinawi H, Al-Qubtan A, Al-Lawati J, Al-Habsi A, Al-Shuraiqi M, et al. Prevalence and determinants of burnout syndrome and depression among medical students at Sultan Qaboos University: a cross-sectional analytical study from Oman. Arch Environ Occup Health. 2019;74(3):130-9. DOI: https://doi.org/10.1080/19338244.2017.1400941

17. Pacheco JP, Giacomin HT, Tam WW, Ribeiro TB, Arab C, Bezerra IM, et. al. Mental health problems among medical students in Brazil: a systematic review and meta-analysis. Rev Bras Psiquiatr [Internet]. 2017 [cited 2018 Oct 11];39(4):369-78. Available from: http://www. scielo.br/pdf/rbp/v39n4/1516-4446-rbp-1516444620172223.pdf

18. Cecil J, McHale C, Hart J, Laidlaw A. Behaviour and burnout in medical students. Med Educ Online [Internet]. 2014 [cited 2018 Oct 11];19:25209. Available from: https:/www.ncbi.nlm.nih.gov/pmc/articles/PMC4145104/

19. Ishak W, Nikravesh R, Lederer S, Perry R, Ogunyemi D, Bernstein C. Burnout in medical students: a systematic review. Clin Teach. 2013;10:242-5. DOI: https://doi.org/10.1111/tct.12014 
20. Vasconcelos EM, De Martino MMF. Predictors of burnout syndrome in intensive care. Rev Gaúcha Enferm [Internet]. 2017 [cited 2018 Oct 11];38(4):e65354. Available from: http://www.scielo.br/pdf/rgenf/v38n4/en_1983-1447-rgenf-38-04-e65354.pdf

21. Ferreira NN, Lucca SR. Burnout syndrome in nursing assistants of a public hospital in the state of São Paulo. Rev Bras Epidemiol [Internet]. 2015 [cited 2018 Oct 11];18(1):68-79. Available from: http://www.scielo.br/pdf/rbepid/v18n1/en_1415-790X-rbepid-18-01-00068.pdf

22. Neves CP, Ribeiro DM. Burnout in undergraduate dental students. Rev ABENO [Internet]. 2016 [citado 2018 out. 11];16(1):39-49. Disponível em: http://revodonto.bvsalud.org/pdf/abeno/v16n1/a05v16n1.pdf

23. Campos JADB, Jordani PC, Zucoloto ML, Bonafé FSS, Maroco J. Burnout syndrome among dental students. Rev Bras Epidemiol [Internet]. 2012 [cited 2018 Oct 11];15(1):155-65. Available from: http://www.scielo.br/pdf/rbepid/v15n1/en_14.pdf

24. Valero-Chillerón MJ, González-Chordá VM, López-Peña N, Cervera-Gasch Á, Suárez-Alcázar MP, Mena-Tudela D. Burnout syndrome in nursing students: an observational study. Nurse Educ Today. 2019;76:38-43. DOI: https://doi.org/10.1016/j.nedt.2019.01.014

25. Manzano-García G, Montañés P, Megías JL. Perception of economic crisis among Spanish nursing students: Its relation to burnout and engagement. Nurse Educ Today. 2017;52:116-20. DOI: https://doi.org/10.1016/j.nedt.2017.02.020

26. Njim T, Mbanga C, Mouemba D, Makebe H, Toukam L, Kika B, et al. Determinants of burnout syndrome among nursing students in Cameroon: cross-sectional study. BMC Res Notes [Internet]. 2018 [cited 2018 Oct 11];11(1):450. Available from: https://www.ncbi.nlm. nih.gov/pmc/articles/PMC6038299/

27. Boni RADS, Paiva CE, Oliveira MA, Lucchetti G, Fregnani JHTG, Paiva BSR, et al. Burnout among medical students during the first years of undergraduate school: prevalence and associated factors. PLoS One [Internet]. 2018 [cited 2018 Oct 11];13(3):e0191746. Available from: https://www.ncbi.nlm.nih.gov/pmc/articles/PMC5841647/

28. Mbanga CM, Efie DT, Aroke D, Njim T. Prevalence and predictors of recreational drug use among medical and nursing students in Cameroon: a cross sectional analysis. BMC Res Notes. 2018;11(1):515. DOI: https://doi.org/10.1186/s13104-018-3631-z

29. Ahola K, Hakanen J, Perhoniemi R, Mutanen P. Relationship between burnout and depressive symptoms: a study using the person-centred approach. Burn Res. 2014;1(1):29-37. DOI: https://doi.org/10.1016/j.burn.2014.03.003

30. Alves LJC, Kendall MC, Vasconcelos EM, Martino MMF, França SPS. Low burnout among intensive care units? Rev Bras Enferm [Internet]. 2018 [cited 2018 Oct 11];71(3):932-3. Available from: http://www.scielo.br/pdf/reben/v71n3/0034-7167-reben-71-03-0932.pdf 